Review

\title{
The Rhetoric of Sustainability: Perversity, Futility, Jeopardy?
}

\author{
Meg Holden \\ Urban Studies Program, Simon Fraser University, 2nd Floor, 515 W. Hastings Street, Vancouver, BC, \\ V6B 5K3, Canada; E-Mail: mholden@ sfu.ca; Tel.: +1-778-782-7888; Fax: +1-778-782-5297.
}

Received: 30 December 2009 / Accepted: 9 February 2010 / Published: 22 February 2010

\begin{abstract}
In 1991, development economist and American public intellectual Albert O. Hirschman wrote the Rhetoric of Reaction [1]. In this book, which was prescient of more contemporary popular books such as Naomi Klein's The Shock Doctrine [2] and James C. Scott's Seeing Like a State [3], Hirschman proposed a way to understand the kinds of arguments made by conservatives about proposals for change. His compelling trilogy of modes of arguments included arguments of perversity, futility, and jeopardy. I argue here that this schema can additionally be used as a way to understand the limits that are seen to exist to approaching sustainable development. I will demonstrate the pervasiveness of arguments that our best attempts to move toward sustainability in our cities today may present threats that are just as grave as those of not acting. This exercise serves two purposes. One is to urge those who would call themselves sustainability scholars to think critically and carefully about the lines of thought and action that may separate different sustainability motivations from the far reaches of interdisciplinary work in this field. The other is to suggest that, because of the persistence of certain kinds of arguments about the impossibility of sustainability, suggestive of deep and enduring instincts of doubt through human history, we should be skeptical of the legitimacy of these claims about the limitations of achieving sustainable development.
\end{abstract}

Keywords: sustainable development; Albert O. Hirschman; pragmatism; planning; social change 


\section{Introduction}

In 1991, development economist and US public intellectual Albert O. Hirschman wrote The Rhetoric of Reaction [1]. In this book, which was prescient of more contemporary popular books such as Naomi Klein's The Shock Doctrine [2] and James C. Scott's Seeing Like a State [3], Hirschman proposed a way to understand the kinds of arguments made by conservatives about proposals for change. Drawing examples from three periods of vociferous reaction to social change-the aftermath of the French Revolution, the nineteenth-century push for universal suffrage, and the rejection of the Welfare State now known as neoliberalism - he tracks the development, deployment and intertwining of arguments about why efforts to direct positive change fail. His study raises some often unstated questions about the psychology of conservatism and the general appeal of such arguments particularly to the media. His compelling trilogy of modes of arguments against change included arguments of perversity, futility and jeopardy. To wit:

Perversity: well-intentioned efforts toward change always backfire and exacerbate the problem one is trying to solve;

Futility: the change will achieve nothing, because it fails to acknowledge incontrovertible political, social or economic laws; the acquisitiveness and selfishness of human nature doom all efforts for social improvement;

Jeopardy: the change will threaten to destroy some cherished previous hard-won accomplishment, such as freedom or democracy.

Hirschman's schema is an attempt to come to grips with the "massive, stubborn, and exasperating otherness of others" (ix), and more specifically, "the systematic lack of communication between groups of citizens, such as liberals and conservatives, progressives and reactionaries" (ix-x). I argue here that this schema can additionally be used as a way to understand the limits that are seen to exist to approaching sustainable development.

It is difficult to go about one's life in these times without being faced with the feeling that these are very dangerous times, for the human race, for the globe itself-but I am not going to bludgeon you with this particular hammer at this juncture. The tool I am going to use bangs in the opposite direction. It may well be that the failure to address the challenges of unsustainability threatens to doom us all along with our precious planet. What if the opposite danger is also true? That is, building upon A.N. Whitehead's maxim that "The major advances in civilization are processes which all but wreck the societies in which they occur", I will demonstrate the pervasiveness of arguments that our best attempts to move toward sustainability today may present threats that are just as grave as those of not acting.

Reactionary arguments against sustainability action are more pervasive than it would seem, in the current context of widespread adoption of the language of sustainability across social and economic sectors and perspectives. Understanding these arguments permits us to understand and pinpoint the anti-sustainability rhetoric that may be couched within diverse definitions and applications of sustainability, and can help us develop a meaningful ontology of sustainability. Such an ontology is needed to navigate the differences among those who call themselves sustainability scholars, students and practitioners in very diverse, interdisciplinary contexts. In addition, putting doubts about 
sustainability advances in the historical perspective of reactionary thought generally should give sustainability change advocates the courage to investigate critically the basis for particular claims against change and to reject those that do not stand up to scrutiny. My goal here is not to engage in this careful scrutiny of anti-sustainability arguments, but to show that they are examples of types of reasoning that have been persistently attractive to reactionaries throughout history. My cases are drawn from planning, policy and development practices at the urban to national scales, but with particular reference to the prospectively sustainable city of Vancouver, Canada, which is my home.

I will argue that the perversity argument is called upon by those who cast the new "entrepreneurial" and "partnership" forms of governance as worse than more traditional, regulatory roles that government has played when it comes to achieving sustainable development. In discussing the use of the argument of futility, I will focus on critiques of participation in sustainable development as being ultimately ineffectual in changing underlying power structures and resource distributions. The jeopardy argument is called upon, I will argue, by those who question the implications of the integrative and holistic aspect of sustainability frameworks within local planning and policy.

Sustainable development is a large tent of ideas about governance and society-nature relationships. The broad-based attractiveness and interdisciplinary appeal of the concept of sustainability is an important aspect of its promise as a policy and planning framework, as an expression of value and virtue, and as a social movement. Because of the broad and vague scope of sustainability, however, it is able to attract reactionaries as well as revolutionaries. Indeed, as some note [4], it is rare indeed in these times to hear anyone speak overtly against sustainability. At the same time, the relationship between sustainability and social change remains ambiguous, unexamined by theorists and unarticulated by practitioners [5]. While the talking heads nod with universal acceptance and use the concept of sustainability as an ideal, those who look a little bit lower will find the hands wringing with reasons why we should not, cannot, or must not change. I want to be clear that in pointing out some of the arguments against such an approach to sustainable development, I am not calling those who make the arguments "conservatives"-we do not need a McCarthy era in the service of sustainability. Instead, I venture that this way of understanding and interpreting the emerging policy and practice of sustainable development can help us understand the potential of initiatives to lead us toward genuinely new approaches to governing, managing, and living in our local spaces and places or, by contrast, whether they represent reinforcing of existing barriers to communication between different groups.

What I am not going to delve into is the meaning of sustainability in any "pure" sense, untainted by the failures, deceits and discolorations of practice. There is a well known and still raging academic debate about this matter [6-9], so any treatment of this here could take the discussion a long ways afield. It would also be unpragmatic of me to give this debate any credence, as it is a pragmatic maxim that "disconnection from practice produces theoretical hallucinations" [10]. Mostly, for our purposes, I think it is more productive to talk about sustainability in terms of how it is purported to make a difference in the creation and maintenance of places of meaning - that is, how we live and operate within and govern our communities. In the planning, policy, and social science literatures related to sustainability, three of the features most commonly called upon with regard to the difference that sustainability makes are its reorganization of the powers and institutions of governance, its emphasis on participative techniques, and its integrative frame. To this end, examining the ways in which a 
sustainability orientation offers promise of or resistance to change in the domain of local governance, participatory processes, or an integrative approach is enough for us to take on in this essay.

Before we enter into Hirschman's scheme, then, a few words about what I mean by a pragmatic approach to sustainable development. When I use the term "pragmatic", I am referring not to the common use of the term but to the philosophy of pragmatism which was developed by American philosophers in the late 19th century New England (members of the elite "Metaphysical Club" that Louis Menand has documented well in his book by the same name [11], in particular Charles Peirce and William James) and a little bit later by other philosophers and social activists in New York and Chicago (in particular, I would note John Dewey and Jane Addams). A few aspects of this philosophy are important to understand for the argument at hand. Pragmatic beliefs are rules for action rather than held for the sake of analytic categories that might have purely abstract value for philosophers. The consideration that beliefs should be judged based on the difference they make in practice makes it impossible to distinguish clearly between what is true in a particular context and what is good, or has moral value. The drive to increase truth value by increasing moral worth motivates continued recruitment of participants in the community of inquirers, that group of citizens in a democracy doing the heavy lifting of knowledge generation and social innovation. Finally, pragmatic philosophy has a particular predilection toward change and the conviction that there might always be "something new under the sun", if for no other reason than because there is always the possibility of new participants in the designation of things to be considered. Because truth is always contextual, it always requires social interpretation, tinkering, and experimentation.

I agree with the environmental pragmatist Bryan Norton [12] that sustainability must be a pragmatic idea if it is to hold any weight in reorienting the societies of the future, because of pragmatism's integrated understanding of assessing outcomes and judging value, and because this orientation radically opens up possibilities for change in the future. Among the many fissures that we might identify under the big tent of sustainability thought, the notion of sustainability has an ambiguous relationship with change. Early formulations of sustainable development, such as that of the International Union for the Conservation of Nature [13], were oriented toward notions of conservation of natural resources, and this flavor or stream of sustainability thinking has persisted, appearing again in research that approaches population policy via the notion of human carrying capacity [14], stronger formulations of the ecological footprint [15], and attempts to reconceptualize an economic system "beyond growth" [16], in which "sustainability is a condition where population is not growing and industrialization and use of resources are not growing" [17]. A pragmatic perspective begins from the opposite pole of this orientation - that it is in experimentation, learning, restoration and relationship-building rather than conservation that hope for the future resides. The challenge at all times is "to get the social organism thinking" [18], stretching individual and narrow self-interests into broader civic interests, more benevolent and democratic habits, and institutions more adequate to build and rebuild better societies. For a longer explication of my meaning of pragmatism in relation to ideas of sustainable development, see Holden [19]. 


\section{Results and Discussion}

Here we consider the three types of reactionary arguments according to Hirschman and how each relates to aspects of arguments about sustainability, within planning, policy and social science literatures, and in relation to practice.

\subsection{Perversity}

As concisely as possible, the logic of the perversity argument is this: everything backfires. Thus, in our context, the argument goes, trying actively to achieve sustainable development will only make unsustainability worse. Here, we are faced with the contention that local sustainability initiatives that embody a new role and organization of local government produce just so much "warmed over neoliberalism" and these initiatives are likely to lead to more bland global monocultures of consumer cities and spayed and neutered local governments which no longer concern themselves with "the public interest". The perversity argument has a long-standing resonance within the reactionary reaches of the sustainability movement. In 1971, Jay Forrester, a member of the Club of Rome and originator of systems theory, wrote an article called "Counterintuitive Behavior of Social Systems" that argued that the complex and highly interactive nature of social systems, including "multi-loop nonlinear feedback systems", makes the outcomes of policy interventions from job retraining programs to welfare likely to be the opposite of what was intended. This situation additionally makes it very unlikely that people themselves will ever understand society. These social systems, according to Forrester, are full of the mysteries of unintended consequences and opposite effects, and this situation compels us to put our energy and faith in computers programmed to disentangle these systems, as "only the highly trained computer specialist can unravel these mysteries" [20].

The perversity argument operates in discourse about sustainability with reference to theories of neoliberalism and governmentality. Here, a variety of scholars, often in the postmarxian or Foucauldian tradition, point to the move toward sustainability in governance as part of the shift toward government as "steering" rather than "rowing" the ship of state [21]. In this realm of discourse and theory, sustainability policy marks a departure from the origins of environmental policy in the 1960s and 70s, which took such forms as Environmental Impact Assessment and Endangered Species legislation (policy "sticks"), and a move toward the use of policy "carrots" - partnerships, facilitative and mediative bodies. Partnership-based sustainability governance approaches take the position that government neither holds sufficient power and resources to enact and enforce new policies alone, nor should it be seen as the traditional "experimenter for the nation" from which new ideas and technologies flow [22]. Instead, the partnership strategy holds, government can play its most effective role in leveraging different resources, understandings and expertise, and finding new solutions by empowering those groups and individuals who are the true experimenters (primarily the private sector, sometimes also including community groups and individual residents) to scale up their good ideas, listening to the ideas of others, modelling best practices on this basis rather than regulating [23].

In characterizing and documenting this shift from government to governance in relation to sustainability, the perversity argument frequently rears its head. This strategy may aim to increase the effectiveness and scope of sustainability policy by creating a more productive policy environment 
where a common stake can be recognized and sought by all actors, but the result is revoking the unique authority of government, and its unique position of protecting the public interest. So, whereas the intent may be to enable private sector actors and private individuals to think and act in terms of the public, civic, long-term interest, the result is that all actors in a partnership wind up thinking like a corporation, with citizens reduced to stakeholder status, in terms of narrow protection of conservative values and NIMBY concerns. In gaining "P3" style public-private partnerships, multistakeholder groups and joint initiatives, we lose the essence of the government-citizen relationship and the best incarnation of both governments and citizens are in fact reduced to the lowest common denominator. As the institutional structure thus shifts, so does the opportunity structure of governance, and no one is left to speak for "the public interest", to represent the "citizens of today and tomorrow", let alone (like Dr. Seuss's Lorax) for the forests and the trees.

A strong example of this kind of perversity argument can be found in the work of UK-based Richard Cowell and Susan Owens. In their 2006 article in Environment and Planning C, Cowell and Owens argue that the planning process in the UK has been responsible for environmental protection and certain kinds of sustainability results via both direct means (green belts, growth management regulations, and development mitigation measures) and indirect means. By indirect means, they refer to the public hearing and other traditional public review processes of plans, which in their opinion have opened up "crucial institutional spaces for challenges to the status quo" [24]. They recount numerous examples from their own research and that of others in which planning in the realm of transportation, mining and minerals, energy, and waste was subject to a serious impact as a result of what transpired at traditional consultation and participation forums. These are the kind of interventions that are familiar to all planning students as the NIMBY (Not In My Backyard), LULU (Locally Unwanted Land Uses) and BANANA (Build Absolutely Nothing Anywhere Near Anything) variety - the kind of confrontational, theatrical and sometimes litigious displays that have, nonetheless, had a positive impact on the sustainability traits of plans in these and other sectors over the past few decades [25]. Cowell and Owens go on to argue that in making the turn toward the explicit creation of sustainability plans and policies, and in emphasizing new partnership and consensus-oriented plan making in this vein, the governance system loses this trusted and effective channel for change. In striving to give planning a "positive" face as opposed to the face of regulations, red tape and adversary, new scalar tensions are introduced through which local concerns and oppositions can be trumped by "strategic" national interests, and particular interests by particular citizens for particular places are lost in the overall quest for a mythical global sustainable future. Tensions are also introduced related to the timing of public input into planning, with the new sustainability planning putting unproven support behind the possibility that engagement with the public at an earlier stage will entail fewer conflicts in the long run - a hypothesis that has received the strong support of the development community, which sees this approach as key to a more "streamlined" and speedy development approval process.

This very argument is part of the interpretation of Vancouver's sustainability planning experience. CityPlan, Vancouver's comprehensive plan, was developed in the early 1990s to much fanfare for its unprecedented level of public participation. The CityPlan process included: 250 idea sharing kitchen tables involving 3,000 individuals, a 3 day ideas fair visited by 10,000 people, a 6,000 person mailing list, a making choices exhibition with 15,000 attendees, and a plebiscite [26]. While the Planning Department bragged of this revolutionary innovation in planning practice, local academics warned that 
"popular sovereignty [had] become a euphemism for abandoning responsible, representative government" [20]. This resentment was well captured by former Chairman of the Vancouver Parks Board, Art Cowie, when he lamented that "the citizen participation process [had] begun to turn into the "tyranny of a few" who look after their own interests at the expense of the wider community" [27]. The intention was just the opposite: "The hope implicit in [the CityPlan process's] ostensible redistribution of power to the public was that it would foster a greater sense of collective proprietary responsibility for planning decisions, and therefore, make otherwise recalcitrant citizens more willing to accept the inevitable trade offs associated with crafting policy" [28].

So what if this wager was wrong? What if, instead of expanding a common understanding of the public interest, participation and partnership in the name of sustainability, this process merely permitted vocal citizens to project their limited self-interests 10,000 times over? A perversity argument on this and other similar processes would hold that public participation in sustainability planning eliminates the only barrier to the worst excesses of development and only neutral arbiter of the city's interests. Such participation may make certain kinds of opposition impossible.

\subsection{Futility}

The futility argument is most aptly stated in French: "plus ça change, plus c'est la même chose". In the context of our discussion here, the futilists claim that participation in sustainable development strategies does nothing to move us toward greater sustainability, because the participation has no impact on actual decisions. Involving more participants may make people feel more involved, but it is cold comfort as their participation does not change the underlying power and decision-making structures.

In this vein, we reference the body of literature on "formulaic" and "Mickey Mouse game" public participation, with its roots in the work of Sherry Arnstein [29] which argues that innovations in the means and modes of participation are ineffective at breaking through the barriers of inequality that exist between groups in the modern city, and in fact they usually only serve to reinforce these inequalities and constraints to new thinking or behaviours, or shared experiences and perceptions [30-33]. The thrust of most of the literature evaluating the impacts of public participation in planning processes suggests that, regardless of the approach used, participation has "limited efficacy in changing policy", in fact, most such processes are doomed to ineffectiveness in this sense, as they fail to allocate sufficient power to participants to implement their desired changes, and more generally, "most have only addressed issues outside the context of an actual policy decision" [34]. Some researchers even go so far as to present evidence that participants in public processes are willingly and knowingly wasting their time. Hayes found that more than double the citizens he interviewed cited "personal commitment" (28.3\%) as the factor that kept them involved in public processes than those who cited "seeing the positive results of actions" (13.2\%). Looking at this issue in reverse, Hayes found that the lack of commitment of others to civic involvement caused much more frustration than did slow progress on issues (cited as a key frustration by $47.5 \%$ of respondents compared to $10 \%$ of respondents, respectively) [35]. If engagement does not affect policy and cannot be expected to improve government-citizen relationships, what good does it serve? 
The futility argument with regard to sustainable development goes beyond a disdain for public participation, however. It can be seen across the spectrum of sustainability initiatives that, for example, raze forests and fragment ecosystems in order to build neighbourhoods that are then labelled "close to nature" and environmentally-sensitive, and often take on the namesake of the places they have destroyed in being built. Here we could reference, in the Vancouver context, a growing suite of property developments built to vaunted sustainability standards, from energy efficient building design to integrated conservation and support of wildlife and water courses, which nonetheless clearcut forests, build roads, and massively increase resource consumption on steep mountain slopes, in the case of the new British Properties development in West Vancouver. We could look at the conversion of old industrial lands to glass-encased signature suites sold at over $\$ 1,000$ per square foot, in the case of Vancouver' Southeast False Creek, a model sustainable neighbourhood [36]. We could also cite Vancouver's success in increasing the participation rate and quantity of household recycling that nonetheless doesn't quite keep pace with the increasing quantity of garbage being produced [37], or greenhouse gas emissions reduction initiatives that are lauded for almost managing to keep the city's emissions stable as development ploughs ahead [38].

Social scientists Kreuger and Agyeman [5] suggest that it is futile to approach sustainability as implying wholesale change to policies and procedures, and that seeking out "actually existing sustainabilities" is a more promising approach. They argue, in effect, that sustainability by any other name would indeed smell as sweet. They propose that despite very limited evidence of effective, named sustainability initiatives in cities across the United States, a search for what they term "actually existing sustainabilities" will uncover ongoing planning and policy work that amounts to the same thing, emerging from "off-the-shelf" business as usual rather than from an explicit sustainability vision or agenda. They suggest the futility of advancing or studying specific sustainability visions or agendas at the local level, because local governments are mostly powerless to translate the lofty concepts of sustainability into actionable strategies, and because a "sustainability" orientation per se has no bearing on the relative sustainability progress being made, as they understand it. Lists and frameworks of principles, charters, and commitments to local sustainability, in the context of this argument, are either disingenuous, duplicitous, or window-dressing, but in any case are not important to the larger pursuit of sustainability, which can only come about in a piecemeal, incremental, manner, if it makes sense as an encompassing framework at all. In moving toward a sustainability framework in all our policy and planning, are we pedaling harder and faster only to stay in the same place?

\subsection{Jeopardy}

Now we have heard that sustainability efforts may backfire, and they may be no more than so much spinning of wheels. Next and finally we consider the possibility that what is going on in the emergence of a dominant sustainable development paradigm is truly diabolical. What if we continue on the path toward sustainable development only to wake up one day to find that all of our hard-won environmental and social safeguards have been lost as we have abandoned these sectoral victories in the name of more holistic, integrative goals of sustainability? The jeopardy argument asserts that emphasis on the holism and integrative nature of sustainable development is a way to avoid going 
deeply into the protections needed to preserve any single element that might be in need of protection - a particular species, a sacred site, a historic building, a group of people.

Here we cannot help but enter somewhat into the definitional debate around sustainability, and in particular the debate regarding "strong" vs. "weak" formulations of sustainability [39]. This distinction was a contribution made by the UK-based environmental economist David Pearce, whose interpretation of the Brundtland definition of sustainable development was that each generation should pass on at least the same stock of capital to the subsequent one. He considered it naive to propose that economic activity never damage the natural environment, and proposed the distinction of different types of capital and the identification of some capital types as non-substitutable as a way to ensure non-declining resources and human welfare over generations. Weak sustainability does not recognize non-substitutable capital stocks, looking only at the single amalgamated bottom-line of changes to manufactured, human, social and natural capitals. Strong sustainability presumes some critical natural capital stocks that are required for welfare, and entails the physical protection of certain absolute levels of natural capital which cannot be substituted without provoking major and unpredictable system perturbations. As vanguard and outlandish as this strong versus weak sustainability distinction made Pearce in the community of economists, subjecting this concept to the real world of sustainability policy evolution reveals that strong sustainability is an idea that has yet to find its way to political palatability. This is where the jeopardy comes in. Weak sustainability may be the only possible route to adoption of sustainability principles in the real world of political compromise, but it may constitute the path to destruction for those very elements that, based on a strong sustainability perspective, we cannot live without.

A jeopardy analysis of an attempt at integrative sustainability work would ask: do we really know how to plan and act in an integrative way toward win-win-win solutions, or is a sectoral analysis of trade-offs the best means we have to protect that which we cannot afford to lose? Here we can turn to the growing practice of corporate social and sustainability reporting that seeks to track and report on a "triple bottom line" of results in financial, social and environmental accounts. Typical practice amongst those corporations and governments pioneering in this field is to consider social and environmental impacts as "adjustments" to financial performance. For example, Chinese President Jintao Hu created that country's Green GDP that adjusted GDP for each region in China based on the cost of environmental clean up [40]. The "nexus point" of environmental, social and economic "bottom lines" remains entirely theoretical, as depicted on the "today" side of Figure 1, which was prepared by the PricewaterhouseCoopers company for a presentation on sustainability accounting. On the "future" side of this figure, recognition of the limitations of this kind of practice has led some companies to aspire towards a new view of financial performance that is constituted by multiple accounts beyond the simply economic. The further aim (or, to use the most appropriate corporate jargon, the "stretch goal"), depicted here in the presentation in Figure 1 from PriceWaterhouseCoopers, is to better understand the relationships among the different accounts, develop a streamlined accounting system able to manage and tabulate all these different sets of information, and create an accounting system that can be used to communicate meaningfully with all stakeholders, not just financial advisors [41]. Making this kind of system operational would require many elements that are not currently possible: a common metric (i.e., dollar equivalents) for all social and environmental goals, high quality and up to date data sources for all these different domains being two key nonexistent 
elements. How serious can a corporation really be about stretching accounting practices this far, considering the immense effort and expense involved in creating such systems, and even assuming that the measurement problems can be resolved? Instead of representing bold, systems-wide vision of a country or a company's impact on the world in which it operates, the triple bottom line may hide damage and deficit accruing persistently behind "door number three" by strong or steady performance behind doors number one and two.

Figure 1. Can there be more than one bottom line? [41].

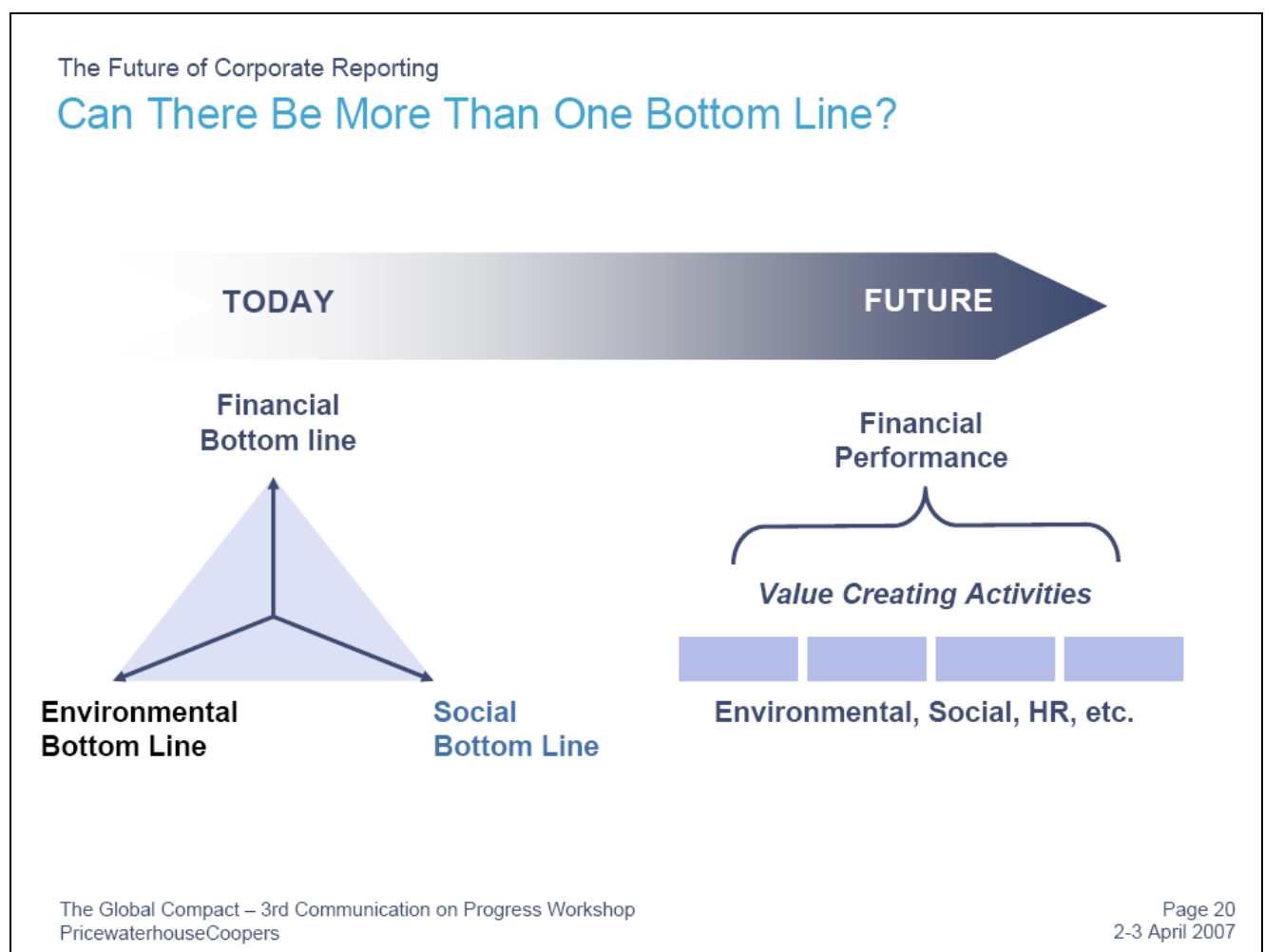

At a broader scale, this is the same kind of aspiration we see in the form of French President Nikolas Sarkozy's new Commission on the Measurement of Economic Performance and Social Progress to report on gross national happiness, and the landmark report released by this initiative on the failures of Gross Domestic Product, the role of rising inequality in societies that fail to be happy, and opportunities for new measures of societal progress [42]. Is it right and good for a nation state to keep tabs on the happiness of its citizens, and determine its progress on this basis? That critiques of the shortcomings of GDP have finally caught up with the global political leadership is welcome to all those working in the field of sustainable development, surely, but we should expect that critiques of this new approach on the horizon are close behind, and that they could be serious. Future scenarios of happiness mandates and checkpoints, among other nightmares of social engineering, come to mind, along with the next generation of Big Brother style centralized accounting systems that absorb more and more energy and attention for less and less meaningful distinctions.

The integration that is aspired to within different quarters of sustainability thinking does not stop at horizontal integration of measures of progress and performance, however. There is, in addition, the question of temporal integration, i.e., the need to be able to consider different time scales and the needs 
of future generations. Further, there is the question of vertical integration across spatial and institutional scales. The notions of "urban metabolism" and the systems-based thinking that is entailed by planning for the city as a mostly or ultimately closed-loop system attempt to summarize the operational side of integrative sustainability thinking [43]. While this approach gains credibility amongst some sustainability thinkers and practitioners [44,45] — as increasing numbers of cities from Calgary [46] to Buenos Aires [47] and beyond attempt 50 or 100 Year Plans, for example-social research questions what this approach does for the social systems within cities. We have more or less reliable models for the ecosphere-dominated components of the urban metabolic system, but what models do we have of social interactions and evolution over medium to long term?

To bring this last point into greater focus, we are all learning, through media bombardment among other channels, the concepts of ecological footprint, the climate "hockey stick" curve, and bioaccumulation of toxins. What mechanisms are we left with for understanding the social sustainability footprint, the possible shape of a social sustainability curve, the accumulation of social sustainability capital? As sustainability researchers, we are bound to communicate the ways in which our social and cultural relationships determine how and how much we appropriate, use and transform nature. Nature may well exist independently of humanity, but given that it is humanity that has the reigns of a possible future sustainable development path, social systems, processes, and institutions need to be at the centre of any attempt to achieve sustainability. If we do not improve our approach in this direction, our efforts to improve environmental quality and conditions under the sustainability banner risk jeopardizing our greatest achievements in the social realm: institutions and understandings of democracy, philosophies of peace and tolerance, movements for social justice, reparations, and reconciliation, and rights for particular disadvantaged groups, from women to indigenous people to the poor and marginalized. A Marxist understanding of sustainability goes so far as to suggest that the way out of the jeopardy of dominant sustainability analyses is to frame the sustainability challenge "as a question of controlling capital at the center of urbanization". Keil explains further: "On the basis of the metabolic and cyborgian character of the city, of its material constitutionality, a politics of sustainability must include an agenda that redirects the devastating force of exchange value-oriented accumulation into a stream of use value-oriented products and services that help sustain human and natural metabolism" [48]. Imagine the result of introducing this perspective on sustainability to the PricewaterhouseCoopers accountants mentioned above.

\section{Conclusion}

Hirschman used the "perversity, futility, jeopardy" schema in an attempt not to draw battle lines or entrench divisions between liberals and conservatives but to show how the discourse that serves to separate these two identity groups in contemporary democratic society is "shaped, not so much by fundamental personality traits, but simply by the imperatives of argument, almost regardless of the desires, character, or convictions of the participants" [49]. I would like to challenge us, as social researchers interested in the prospect of sustainability at home in our communities and at the global scale, to face up to the arguments made in the name of the perversity, futility and jeopardy of sustainable development. In so doing, we will enhance our ability to understand and address our critics, 
strengthen our own position and sense of personal resolve and distinguish serious objections to sustainability initiatives from spurious and formalistic ones.

The discourse of sustainable development, as presented by its proponents, tends toward the presentation of the ideal world-ecotopia, shangrila, lotusland. We can be grateful that such ideals are multiple, diverse, changing, and contingent. Taking cues from the philosophy of pragmatism, effective interdisciplinary analysis of sustainability needs to be about the push and pull of more and less persuasive arguments about the desirability and viability of the full range of these ideals as well as about the critique of competing worldviews and the realization and implications of the absence of any single best case scenario, now or at any time in the future. In engaging in this important and necessary critique, however, scholars of sustainability should beware of conclusions either that this could be the best of all possible worlds or that it is the worst of all possible worlds. Unintended consequences do of course exist, but they may as often be welcome as perverse. Experiments in new processes and new strategies may fail to affect practice in the near term, but we should be slow to cry futility, as sometimes meaningful implementation effects take much longer than we would hope to appear. In Hirschman's words: "The trouble ... is that futility is proclaimed too soon. The first evidence that a program does not work in the way announced or intended, that it is being stymied or deflected by existing structures and interests, is seized upon. There is a rush to judgment and no allowance is made for social learning or for incremental, corrective policy-making" [50]. Jeopardy can result from ambitious attempts to change existing practice, and threats of losing ground on hard-won gains require vigilance, but so does the potential social learning value of engaging in work toward sustainability, beyond direct implementation effects.

Sustainability thought and practice currently span the spectrum of political perspectives. In this way, sustainability offers an exciting universal call for unity and action [51]. This diversity, however, also compels serious sustainability scholars to develop an ontology of sustainability meanings and understandings, with particular reference to the action-orientation of different sustainability formulations. A pragmatic approach to sustainability thinking and action requires just this: a means to distinguish those sustainability efforts that orient us toward change and those that orient us toward preservation of the status quo, as a first cut distinction, and, what is infinitely more difficult, a means to distinguish the quality of change or preservation that is entailed in different sustainability strategies. What pragmatist John Dewey [52] claimed for the realization of democracy we might just as well aspire to regarding the realization of sustainability:

The old saying that the cure for the ills of democracy is more democracy is not apt if it means that the evils may be remedied by introducing more machinery of the same kind as that which already exists, or by refining and perfecting that machinery. But the phrase may also indicate the need of returning to the idea itself, of clarifying and deepening our apprehension of it, and of employing our sense of its meaning to criticize and re-make its political manifestations. 


\section{Acknowledgements}

This essay is based on a keynote address presented at the November 2009 conference entitled "Psychogeographies of Possibility: Re-imagining spaces in critical times" held at the University of Guelph, Ontario, Canada.

\section{References and Notes}

1. Hirschman, A.O. The Rhetoric of Reaction: Perversity, Futility, Jeopardy; Belknap Press: Cambridge, MA, USA, 1991.

2. Klein, N. The Shock Doctrine: The Risk of Disaster Capitalism; Metropolitan Books/Henry Holt: New York, NY, USA, 2007.

3. Scott, J.C. Seeing Like State: How Certain Schemes to Improve the Human Condition Have Failed; Yale University Press, New York, NY, USA, 1998.

4. Swyngedouw, E. Impossible "sustainability" and the postpolitical condition. In The Sustainable Development Paradox: Urban Political Economy in the United States and Europe; Krueger, R., Gibbs, D., Eds.; Guilford Press: New York, NY, USA, 2007; pp. 13-40.

5. Krueger, R.; Agyeman, J. Sustainability schizophrenia or "actually existing sustainabilities?" toward a broader understanding of the politics and promise of local sustainability in the US. Geoforum 2005, 36, 410-417.

6. Redclift, M. Sustainable development (1987-2005): An oxymoron comes of age. Sustain. Dev. 2007, 13, 212-227.

7. Glasmeier, A.K.; Farrigan, T.L. Poverty, sustainability, and the culture of despair: Can sustainable development strategies support poverty alleviation in America's most environmentally challenged communities? Ann. Amer. Acad. Polit. Soc. Sci. 2003, 590, 131-149.

8. Berke, P. Does sustainable development offer a new direction for planning? Challenges for the twenty-first century. J. Plan. Lit. 2002, 17, 21-36.

9. Pezzoli, K. Sustainable development: A transdisciplinary overview of the literature. J. Environ. Plan. Manag. 1997, 40, 549-574.

10. Rorty, R. Achieving Our Country: Leftist Thought in Twentieth-Century America; Harvard University Press: Cambridge, MA, USA, 1998.

11. Menand, L. The Metaphysical Club; Farrar, Straus \& Giroux: New York, NY, USA, 2001.

12. Norton, B.G. Pragmatism, adaptive management, and sustainability. Environ. Value. 1999, 8, 451-466.

13. World Conservation Strategy; International Union for the Conservation of Nature and Natural Resources (IUCN), United Nations Environment Programme and World Wildlife Fund: Gland, Switzerland, 1980.

14. Bartlett, A.A. Reflections on sustainability, population growth, and the environment-2006. In The Future of Sustainability; Keiner, M., Ed.; Springer: Dordrecht, The Netherlands, 2006; pp. 17-38.

15. Rees, W.; Wackernagel, M. Urban ecological footprints: why cities cannot be sustainable — and why they are a key to sustainability. Environ. Impact Assess. Rev. 1996, 16, 223-248. 
16. Daly, H. Beyond Growth: The Economics of Sustainable Development; Beacon Press: Boston, MA, USA, 1996.

17. The loop you can't get out of-An interview with Jay Forrester. MIT Sloan Management Review, 8 January 2009; Available online: http://sloanreview.mit.edu/the-magazine/articles/2009/winter/ 50201/the-loop-you-cant-get-out-of (accessed on 1 February 2010).

18. Menand, L. The Metaphysical Club; Farrar, Straus \& Giroux: New York, NY, USA, 2001; p.287.

19. Holden, M. The tough minded and the tender minded. Plan. Theor. Pract. 2008, 9, 475-496.

20. Hirschman, A.O. The Rhetoric of Reaction: Perversity, Futility, Jeopardy; Belknap Press: Cambridge, MA, USA, 1991; p. 32.

21. Rhodes, R. Understanding Governance: Policy Networks, Governance, Reflexivity and Accountability; Open University Press: Buckingham, UK, 1997.

22. Schön, D. Beyond the Stable State; Random House: New York, NY, USA, 1971.

23. Teisman, G.; Klijn, E.H. Partnership arrangements: governmental rhetoric or governance scheme? Public Admin. Rev. 2002, 62, 197-205.

24. Cowell, R.; Owens, S. Governing space: Planning reform and the politics of sustainability. Environ. Plan. C-Gov. Policy 2006, 24, 405.

25. Schively, C. Understanding the NIMBY and LULU phenomena: Reassessing our knowledge base and informing future research. J. Plan. Lit. 2007, 21, 255-266.

26. McAfee, A. Vancouver's CityPlan: People participating in planning. Plan Canada 1997, 35, 15-16.

27. Artibise, A.; Seelig, M. Future growth: Future shock. The Vancouver Sun, 13 November 1990.

28. Kear, M. Spaces of transition spaces of tomorrow: Making a sustainable future in Southeast False Creek, Vancouver. Cities 2007, 24, 329.

29. Arnstein, S. A ladder of citizen participation. J. Amer. Inst. Plan. 1969, 35, 216-224.

30. Murphy, P.; Cunningham, J. Organizing for Community Controlled Development; Sage: Thousand Oaks, CA, USA, 2003.

31. Cooke, B.; Kothari, U. Participation: The New Tyranny? ZED Books: New York, NY, USA, 2001.

32. Participation, from Tyranny to Transformation? Exploring New Approaches to Participation in Development; Hickey, S., Mohan, G., Eds.; Belknap Press: Cambridge, MA, USA, 2004.

33. Special Issue: Participatory Approaches in Community Development: Transitions and Transformations. Community Develop. J. 2008, 43.

34. Konisky, D.M.; Beierle, T.C. Innovations in public participation and environmental decision making: examples from the Great Lakes Region. Soc. Nat. Resour. 2001, 14, 823.

35. Hayes, R.A. Community activists' perceptions of citizenship roles in an urban community: A case study of attitudes that affect community engagement. J. Urban Aff. 2007, 29, 419.

36. Bula, F. City of Vancouver hands over athletes' village. Globe and Mail, 4 November 2009.

37. Metro Vancouver Sustainability Report; Metro Vancouver: Burnaby, Canada, 2009.

38. Pander, S. Climate Protection Progress Report 2007; City of Vancouver Administrative Report: Vancouver, Canada, 2007.

39. Pearce, D.; Atkinson, G. Capital theory and the measurement of sustainable development: An indicator of "weak" sustainability. Ecol. Econ. 1993, 8, 103-108. 
40. Kahn, J.; Yardley, J. As China roars, pollution reaches deadly extremes. New York Times, 26 August 2007.

41. PricewaterhouseCoopers, Markus Nöthinger. Integrated (sustainability) reporting from the business perspective. In Proceedings of the Global Compact-3rd Communication on Progress Workshop, Geneva, Switzerland, 2 April 2007. Reprinted with permission.

42. Stiglitz, J.; Sen, A.; Fitoussi, J.-P. Report by the Commission on the Measurement of Economic Performance and Social Progress; Commission on the Measurement of Economic Performance and Social Progress: Paris, France, 2009.

43. Holman, P.; Devane, T.; Cady, S. The Change Handbook, 2nd ed.; Berrett-Koehler Publishers: San Francisco, CA, USA, 2007.

44. Girardet, H. Cities, People, Planet: Liveable Cities for a Sustainable World; Wiley-Academy: Chichester, PA, USA, 1992.

45. Newman, P.; Jennings, I. Cities as Sustainable Ecosystems; Island Press: Washington, DC, USA, 2008.

46. Imagine Calgary Plan for Long Range Urban Sustainability; Imagine Calgary: Calgary, Canada, 2006; Available online: http://www.imaginecalgary.ca/imagineCALGARY_long_range_plan.pdf (accessed on 1 February 2010).

47. Espacio Buenos2050Aires2050: Imágenes del Future/Decisions del Presente; Available online: http://www.buenosaires2050.org (accessed on 1 February 2010).

48. Keil, R. Sustaining modernity, modernizing nature: the environmental crisis and the survival of capitalism. In The Sustainable Development Paradox: Urban Political Economy in the United States and Europe; Krueger, R.; Gibbs, D., Eds.; Guilford Press: New York, NY, USA, 2007; pp. 59-60.

49. Hirschman, A.O. The Rhetoric of Reaction: Perversity, Futility, Jeopardy; Belknap Press: Cambridge, MA, USA, 1991.

50. Hirschman, A.O. The Rhetoric of Reaction: Perversity, Futility, Jeopardy; Belknap Press: Cambridge, MA, USA, 1991; p. 78.

51. Connelly, J. The virtues of environmental citizenship. In Environmental Citizenship; Dobson, A., Bell, D., Eds.; MIT Press: Cambridge, MA, USA, 2006.

52. Dewey, J. Search for the great community. In The Philosophy of John Dewey; McDermott, J.J., Ed.; University of Chicago Press: Chicago, IL, USA, 1981; p. 621.

(C) 2010 by the authors; licensee Molecular Diversity Preservation International, Basel, Switzerland. This article is an open-access article distributed under the terms and conditions of the Creative Commons Attribution license (http://creativecommons.org/licenses/by/3.0/). 